7. Рішення Європейського суду з прав людини від 05.03.2020 p. «Іванко проти України». База даних «Законодавство України». URL: https://zakon.rada.gov.ua/laws/show/974_e80\#n45 (дата звернення: 01.07.2021).

DOI https://doi.org/10.30525/978-9934-26-179-4-51

\title{
ДО ПИТАННЯ ЩОДО ОСОБЛИВОСТЕЙ КРИМІНАЛЬНОЇ ВІДПОВІДАЛЬНОСТІ ТА ЗДІЙСНЕННЯ КРИМІНАЛЬНИХ ПРОВАДЖЕНЬ ЩОДО НЕПОВНОЛІТНІХ
}

\author{
Томчук I. O. \\ кандидат юридичних наук, \\ дочент кафедри права \\ Галииький коледж імені В'ячеслава Чорновола \\ м. Тернопіль, Україна \\ Денисовський М. Д. \\ кандидат юридичних наук, \\ дочент кафедри права \\ Галииький коледж імені В'ячеслава Чорновола \\ м. Тернопіль, Україна \\ Кладько В. Ю. \\ здобувач вищої освіти юридичного відділення \\ Галицький коледж імені В'ячеслава Чорновола \\ м. Тернопіль, Украӥна
}

Порядок кримінального провадження щодо неповнолітніх визначається загальними правилами та врахуванням особливостей глави 38 Кримінального процесуального кодексу України (далі КПК України). Кримінальне провадження щодо неповнолітньої особи, в тому числі, якщо кримінальне провадження здійснюється щодо декількох осіб, хоча б одна 3 яких є неповнолітньою, здійснюється слідчим, який спеціально уповноважений керівником органу досудового розслідування на здійснення досудових розслідувань щодо неповнолітніх. Під час кримінального провадження щодо неповнолітнього, в тому числі під час провадження щодо застосування примусових заходів виховного характеру, слідчий, прокурор, слідчий суддя, суд та всі інші особи, що беруть у ньому участь, зобов'язані 
здійснювати процесуальні дії в порядку, що найменше порушує звичайний уклад життя неповнолітнього та відповідає його віковим та психологічним особливостям, роз'яснювати суть процесуальних дій, рішень та їх значення, вислуховувати його аргументи при прийнятті процесуальних рішень та вживати всіх інших заходів, спрямованих на уникнення негативного впливу на неповнолітнього [1].

Установлюючи особливості, законодавець виходив 3 психологічної характеристики цього віку - нестійкості психічних процесів, відсутності достатнього життєвого досвіду, знань і навичок, соціальної поведінки. Зазначені особливості не протиставляються загальним інститутам відповідальності та покарання, а деталізують щодо неповнолітніх зміст і межі загальних інститутів, виходячи з реальних особистих особливостей неповнолітніх. Законодавець визнає, що неповнолітній - це злочинець особливий, який потребує не лише примусового впливу, але і захисту з боку суспільства та держави. У зв'язку з цим кримінальна відповідальність неповнолітніх, особливо у формі покарання, коригується низкою спеціальних норм [2, с. 177-178].

Слід зауважити, що в провадженні щодо неповнолітніх підозрюваних або обвинувачених обов'язково беруть участь батьки або інші законні представники (ст. 488 КПК України), а також представник служби у справах дітей. У виняткових випадках, коли участь законного представника може завдати шкоди інтересам неповнолітнього підозрюваного чи обвинуваченого, суд за його клопотанням, клопотанням прокурора чи за власною ініціативою своєю ухвалою має право обмежити участь законного представника у виконанні окремих процесуальних чи судових дій або усунути його від участі у кримінальному провадженні і залучити замість нього іншого законного представника.

На відміну від загального порядку виклику в кримінальному провадженні, неповнолітній підозрюваний, обвинувачений викликається до слідчого, прокурора, слідчого судді, суду через його батьків або інших законних представників, яким надсилається відповідна повістка про виклик. Інший порядок виклику допускається, коли це обумовлено обставинами встановленими під час кримінального провадження, зокрема: відсутності у неповнолітнього батьків; приводу неповнолітнього; доцільність негайного допиту або проведення іншої слідчої (розшукової) дії, без залучення законного представника, якщо $є$ підстави вважати, що він може негативно вплинути на неповнолітнього.

Однією 3 особливостей провадження у зазначених справах $\epsilon$ розширення меж предмета доказування. Тому крім обставин, встановлення яких $\epsilon$ обов'язковим під час провадження кожної кримінальної справи, у справах про злочини неповнолітніх згідно 
зі ст. 485 КПК України необхідно також з'ясувати: вік неповнолітнього; стан його здоров'я та загального розвитку; характеристику особи, умови життя і виховання неповнолітнього; обставини, що негативно впливали на його виховання; наявність дорослих підбурювачів та інших осіб, які втягнули неповнолітнього в злочинну діяльність. Не встановлення зазначених обставин свідчить про істотну неповноту провадження у справі і суд може повернути справу на додаткове розслідування.

Разом 3 тим виключно неповнолітніх можна звільнити від кримінальної відповідальності із застосуванням примусових заходів виховного характеру (ст. 97 Кримінального кодексу України (далі - КК України)). Відповідно до ст. 97 КК України неповнолітній, який уперше вчинив кримінальний проступок або необережний нетяжкий злочин, якщо буде визнано, що його виправлення можливе без застосування покарання, може бути звільнений від кримінальної відповідальності із застосуванням до нього примусових заходів виховного характеру, передбачених ч. 2 ст. 105 КК України.

Здійснюючи кримінальне провадження щодо неповнолітніх, у кожному окремому випадку слідчі судді, суд зобов'язані:

- сумлінно і принципово виконувати повноваження із судового контролю за дотриманням прав, свобод та інтересів неповнолітніх осіб у кримінальному провадженні як під час досудового розслідування, так під час судового провадження, діяти у межах і відповідно до вимог закону;

- зважати, що особа набуває повної кримінально-процесуальної дієздатності лише 3 досягненням повноліття, незалежно від акту емансипації, вступу особи у шлюб чи народження нею дитини;

- пам'ятати, що закріплений законом особливий підхід до неповнолітніх правопорушників зумовлює застосування інших, відмінних від тих, які застосовуються до дорослих, форм реалізації кримінальної відповідальності;

- враховувати, що регламентований процесуальним законом особливий порядок здійснення кримінального провадження щодо неповнолітніх поширюється і на осіб, які досягли повноліття під час здійснення кримінального провадження, а також на випадки, коли особа в одному кримінальному провадженні обвинувачується у вчиненні кримінальних правопорушень, частину з яких нею вчинено до, а решту - після досягнення 18 років;

- пам'ятати, що кримінальне провадження щодо неповнолітньої особи має бути здійснено невідкладно i розглянуто в суді першочергово [3]. 
У випадку, коли вину неповнолітньої особи вже доведено, до неї може бути застосовано п'ять основних видів покарань: штраф, громадські роботи, виправні роботи, арешт та позбавлення волі на певний строк. Штраф застосовується до неповнолітнього, який має власний дохід, чи кошти на які може бути звернено стягнення. Громадські виправні роботи та арешт застосовуються лише до осіб віком від 16 років до 18 років. Тому у віці від 14 до 16 років при призначенні неповнолітньому покарання залишається в переважній більшості можливість призначення лише покарання у виді позбавлення волі, що нівелює, в свою чергу, принцип індивідуалізації покарання, його справедливості та гуманізму [4, с. 195-196].

Тому, підсумовуючи вищевикладене, можна зробити висновок, що враховуючи особливості здійснення кримінального провадження щодо неповнолітніх слідчий, прокурор, слідчий суддя та суд деталізують процес розгляду справ та надають велике значення відповідальності та захисту прав неповнолітнього. Положення КПК України врегульовують забезпечення прав та законних інтересів неповнолітніх осіб 3 цього приводу, проте ряд норм все-таки потребують уточнення, внесення відповідних змін та доповнень. При цьому слід враховувати, що чільне місце серед виявлення та протидії кримінальних правопорушень, вчинених неповнолітніми, а також розроблення загальних заходів профілактики таких правопорушень належить саме процесуальній діяльності органів розслідування, прокуратури та суду. Саме тому, підвищення якості досудового розслідування i судового процесу в справах щодо неповнолітніх сприятиме зменшенню проявів такої злочинності.

Щодо призначення покарання неповнолітнім у віці від 14 до 16 років, вважаємо, що в цьому напрямку важливими $є$ зміни до КК України в частині уникнення випадків можливості безальтернативного призначення покарання у виді позбавлення волі. Залишити його доцільним буде лише у випадках вчинення особливо тяжкого злочину, в тому числі поєднаного з умисним позбавленням життя людини.

\section{Література:}

1. Кримінальний процесуальний кодекс України від 13.04.2012. № 4651-VI. Дата оновлення: 08.08.2021. URL:https://zakon.rada.gov.ua/ laws/show/4651-17\#n3880 (дата звернення: 29.09.2021).

2. Казначеєва Д.В. Проблеми призначення покарання щодо неповнолітніх. Вісник кримінологічної асоиіаиії Украӥни.2020. № 1 (22). C. 176-182. URL:http://dspace.univd.edu.ua/xmlui/bitstream/handle/ 123456789/8303/Problemy\%20pryznachennia\%20pokarannia\%20shchodo\% 
20nepovnolitnikh_Kaznacheieva_2020.pdf? sequence $=2 \&$ isAllowed $=\mathrm{y}$ (дата звернення 03.11.2021).

3. Про деякі питання здійснення кримінального провадження щодо неповнолітніх: Лист Вищого спеціалізованого суду України з розгляду цивільних і кримінальних справ від 18.07.2013. № 223-1134/0/4-13. URL: https://zakon.rada.gov.ua/laws/show/v1134740-13\#Text.

4. Томчук I. Застосування покарань до неповнолітніх: проблемні питання. Науковий вісник Херсонського державного університету. Серія: «Юридичні науки». 2014. Вип. 4. Том 2. С. 194-198.

\title{
DOI https://doi.org/10.30525/978-9934-26-179-4-52
}

КОНТРОЛЬ ЗА ДОТРИМАННЯМ РОЗУМНИХ СТРОКІВ ДОСУДОВОГО РОЗСЛІДУВАННЯ ПРОКУРОРОМ ВИЩОГО РІВНЯ ЯК ВАЖЛИВА ГАРАНТІЯ ЗАБЕЗПЕЧЕННЯ ПРАВА НА ДОСТУП ДО ПРАВОСУДДЯ, ГАРАНТОВАНОГО Ч. 1 СТ. 6 КОНВЕНЦІЇ ПРО ЗАХИСТ ПРАВ ЛЮДИНИ ТА ОСНОВОПОЛОЖНИХ СВОБОД

\author{
Шевчук М. I. \\ кандидат юридичних наук, \\ дочент кафедри кримінального прочесу і криміналістики \\ Львівський національний університет імені Івана Франка \\ м. Львів, Украӥна
}

Право на доступ до правосуддя включає в себе такі елементи: право особи звернутися до суду, право на те, щоб ії справа була розглянута та вирішена судом, право на остаточне судове рішення, право на оскарження судового рішення, право на виконання судового рішення, ухваленого на користь особи (рішення Європейського суду з прав людини (далі - ЄСПЛ) у справах «Беллет проти Франції» від 04.12.1995 p., «Брумареску проти Румунії» від 28.10.1999 р., «Горнсбі проти Греції» від 19.03.1997 р., «Балацький проти України» від 25.10.2007 p.).

ЄСПЛ у своїй практиці неодноразово наголошував, що право на доступ до правосуддя не $\epsilon$ абсолютним: воно може бути піддане допустимим обмеженням, оскільки вимагає за своєю природою державного регулювання. Держави-учасниці користуються у цьому 